\title{
Anti-angiogenic agents in the treatment of non-small cell lung cancer
}

\author{
Katarzyna Szyszka-Barth ${ }^{1}$, Katarzyna Ramlau², Dariusz Stencel ${ }^{3}$, Rodryg Ramlau ${ }^{4}$ \\ ${ }^{1}$ Department of Clinical Oncology, Wielkopolska Center of Pulmonology and Thoracic Surgery \\ of Eugenia and Janusz Zeyland, Poznan, Poland \\ ${ }^{2}$ Clinical Hospital of Lord's Transfiguration, Poznan University of Medical Sciences, Poznan, Poland \\ ${ }^{3}$ Boehringer Ingelheim Marketing Sp. z o.o, Warsaw, Poland \\ ${ }^{4}$ Department of Oncology, Clinic of Oncology, Poznan University of Medical Sciences, Poznan, Poland
}

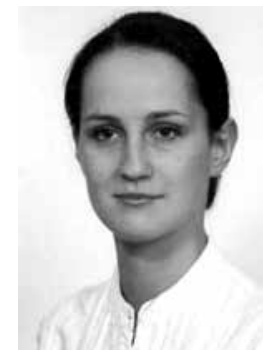

Kardiochirurgia i Torakochirurgia Polska 2014; 11 (2): 145-150

\begin{abstract}
Lung cancer is the most common malignant neoplasm diagnosed worldwide. In Poland, in 2011, lung cancer was diagnosed in 14,522 men and 6,283 women. Morbidity and mortality are nearly equal, and lung cancer is still the most common cause of cancer-related death among men as well as among women. Approximately $80 \%$ of lung cancer cases are non-small-cell lung cancer. The most commonly applied chemotherapy regimens do not produce satisfactory effects. Oncological research is now focused on molecular targeted therapies; immunotherapy is also under evaluation. The formation of abnormal blood vessels has an enormous impact on the development and progression of a tumor. Bevacizumab is a monoclonal antibody which binds VEGF (vascular endothelial growth factor). A different group of drugs is constituted by small-molecule antiangiogenic tyrosine kinase inhibitors. These agents represent a different profile of side effects in comparison to chemotherapy. The mode of action, differing from cytotoxic drugs, requires renewed analysis as well as standardization of radiological response assessment criteria. Key words: antiangiogenic treatment, non-small-cell lung cancer, bevacizumab, nintedanib.
\end{abstract}

\section{The role and process of angiogenesis in the development of a neoplasm}

The development and growth of a neoplasm requires an appropriate supply of oxygen, nutrition, growth factors, hormones, and proteolytic enzymes [1]. The neoplasm cannot increase its dimensions to more than $2-3 \mathrm{~mm}^{3}$ without the formation of new blood vessels (angiogenesis). Blood vessels that develop as a result of pathological angiogen-

\section{Streszczenie}

Rak płuca jest najczęściej rozpoznawanym nowotworem złośliwym na świecie. W Polsce na raka płuca w 2011 r. zachorowało 14522 mężczyzn i 6283 kobiety. Liczby zgonów i zachorowań są niemal identyczne, a rak płuca jest nadal najczęstszą przyczyną zgonów z przyczyn nowotworowych u mężczyzn, a także u kobiet. Około 80\% wszystkich rozpoznań stanowi niedrobnokomórkowy rak płuca. Najczęściej stosowane schematy chemioterapii nie przynoszą zadowalających efektów. Rozwój onkologii koncentruje się na terapiach ukierunkowanych na cele molekularne, trwają również badania kliniczne nad immunoterapią. Duże znaczenie w powstawaniu i zwiększaniu wymiarów nowotworu ma rozwój nieprawidłowych naczyń krwionośnych. Bewacyzumab jest przeciwciałem monoklonalnym wiążącym się z czynnikiem wzrostu śródbłonka naczyniowego (vascular endothelial growth factor - VEGF). Odmienną grupą leków są drobnocząsteczkowe inhibitory kinaz tyrozynowych zaangażowanych w proces angiogenezy. Leki te prezentują odmienny profil działań niepożądanych w porównaniu ze standardową chemioterapią. Odmienny mechanizm działania wymaga również ponownej analizy i ujednolicenia kryteriów radiologicznej odpowiedzi na leczenie.

Słowa kluczowe: leki antyangiogenne, niedrobnokomórkowy rak płuca, bewacyzumab, nintedanib.

esis are abnormal; they do not form hierarchical networks, their diameter is variable, they are kinked, dilated, and they form sac-like structures. They are also characterized by increased permeability [3-6]. The abnormal distribution of chemical therapeutics is intensified by the uneven distribution of blood vessels within the tumor, the pressure exerted by proliferating tumor cells, and the turbulent and chaotic blood flow through the pathological vessels [7]. 
As with most solid tumors, numerous clinical studies have confirmed that, in lung cancer, a high density of small vessels in the tumor is an unfavorable prognostic factor and correlates with metastasis formation [8-12].

The process of angiogenesis, both physiological and pathological, is initiated at the moment when the balance between anti-angiogenic and pro-angiogenic factors shifts towards the latter. In the case of a tumor, the phenotype of the tumor cells is then changed to an invasive one.

\section{The mechanism of angiogenesis in lung cancer}

The best understood mechanism of angiogenesis is the sprouting of new blood vessels in the direction of neoplastic cells, consisting in the proliferation and migration of endothelial cells from previously existing vessels and the formation of tubular vascular structures. The key factor in this process is vascular endothelial growth factor (VEGF). VEGF-A induces the distention of existing blood vessels and increases their permeability. Plasma proteins, particularly fibrinogen, undergo extravasation and accumulate in the extracellular space, while metalloproteinases are activated, and the concentration of the plasminogen activator increases, causing the degradation of the extracellular matrix, which facilitates the migration of endothelial cells [1315]. Platelet-derived growth factor (PDGF) causes pericytes to accumulate in the vicinity of the newly formed vessels.

\section{Factors regulating the process of angiogenesis}

A disturbance in the balance between the activity of factors which stimulate and inhibit angiogenesis in favor of the pro-angiogenic factors initiates the process of forming new vessels. The primary and best understood pro-angiogenic factor is vascular endothelial growth factor (VEGF-A). Its glycoprotein family also includes VEGF-B, VEGF-C, VEGF-D, VEGF-E, and placental growth factor (PIGF). VEGF-A was initially defined by Dvorak et al. as vascular permeability factor (VPF) [16]. Out of the 4 isoforms of the VEGF-A gene, $\mathrm{VEGF}_{165}$ is dominant. VEGF-A plays a key role both in physiological angiogenic processes (during wound healing, ovulation, menstruation, and pregnancy) and in pathological processes (such as diabetic retinopathy, macular degeneration, and psoriasis) $[17,18]$. Hypoxia is the primary factor stimulating VEGF synthesis through the activation of hypoxia-inducible factor- $1 \alpha$ (HIF1 $\alpha)$. The most important property of VEGF is the increase of vascular permeability, even up to 50,000 stronger than that resulting from histamine action, in the vascular bed of the skin, peritoneum, mesentery, and diaphragm, among others. This can lead to the occurrence of pleural or peritoneal effusion, while inhibiting the function of VEGF reduces the occurrence of these conditions, as confirmed by conducted studies [19, 20]. VEGF also causes vascular distention by releasing nitric oxide and prostaglandins from endothelial cells. This results in a transient acceleration of heart action and a reduction in arterial pressure and cardiac output. The effect of inhibiting VEGF activity may also be responsible for the adverse reactions to anti-angiogenic therapies observed in clinical studies, such as headaches or arterial hypertension [17]. VEGFR-2 (vascular endothelial growth factor receptor-2) binds to VEGF-A, but also to VEGF-C and VEGF-D; it is the dominant receptor by means of which VEGF exerts its mitogenic and angiogenic activity and increases the permeability of blood vessels. It has been demonstrated that a high concentration of VEGF in lung cancer is an independent negative prognostic factor. Medications aimed at inhibiting VEGF activity constitute a promising therapeutic option because VEGF circulates in peripheral blood and acts directly on endothelial cells, which does not require the medication to penetrate into the neoplastic tissue in order to impede angiogenesis. Moreover, endothelial cells influenced by VEGF inhibitors are less likely to change their phenotype to one that is resistant to treatment than the genetically unstable neoplastic cells [21].

\section{Platelet-derived growth factor}

The family of platelet-derived growth factors (PDGF) influences the angiogenic process by regulating the survival of endothelial cells and by recruiting pericytes, smooth muscle cells, and tumor-associated fibroblasts producing VEGF [22-24]. High concentrations of immunohistochemically labeled PDGF result in worse prognoses in lung cancer patients [25].

\section{Bevacizumab}

Bevacizumab is a recombinant humanized monoclonal antibody (93\% human and $7 \%$ murine), the action of which consists in binding with free vascular endothelial growth factor (all VEGF-A isoforms), thus inhibiting the combination of VEGF and receptors of Flt-1 (VEGFR-1) and KDR (VEGFR-2) on the surface of the endothelium. It is the first anti-angiogenic agent which was proven by clinical studies to exert a favorable influence on patient survival time in combination with chemotherapy. A phase II trial assessing the efficacy and safety of bevacizumab dosed at 7.5 or $15 \mathrm{mg} / \mathrm{kg}$ in combination with chemotherapy (carboplatin and paclitaxel) demonstrated the prolongation of time to progression (7.4 months vs. 4.2 months, $p=0.023$ ) and the prolongation of overall survival (17.7 months vs. 14.9 months, $p=0.63$ ) achieved with the dose of $15 \mathrm{mg} / \mathrm{kg}$, which turned out to be more successful. Six out of 66 patients treated with bevacizumab suffered from massive hemoptysis; 4 of them died due to a lethal lung hemorrhage from centrally located tumors located in the vicinity of large vessels with the presence of cavitation. Additionally, it has been established that the diagnosis of squamous carcinoma is a risk factor for bleeding. Consequently, multicenter, randomized clinical phase III trials were conducted in order to assess the efficacy and safety of bevacizumab in combination with chemotherapy as a first-line therapy for patients with non-small-cell non-squamous lung cancer. In order to reduce the risk of bleeding, the exclusion criteria included, among others, a histological diagnosis of squamous carcinoma, metastasis within the central nervous system, anticoagulant treatment, and massive hemopty- 
sis in the patient's medical history. Study E4599 included 878 patients with recurrent or advanced non-squamous non-small-cell lung carcinoma. The patients received chemotherapy (carboplatin AUC 6 with paclitaxel $200 \mathrm{mg} / \mathrm{m}^{2}$ ) every 3 weeks with bevacizumab dosed at $15 \mathrm{mg} / \mathrm{kg}$ or with placebo. Longer overall survival (12.5 months vs. 10.2 months, $p=0.0075$ ), longer progression-free survival (PFS: $6.4 \mathrm{vs}$. 4.5 months, $p<0.0001)$, and an increased treatment response rate (35\% vs. $15 \%)$ were observed in the study arm with bevacizumab. Fifteen deaths were noted in the bevacizumab group, including 5 due to pulmonary hemorrhage. The same study demonstrated that an initially low concentration of intercellular adhesion molecules (ICAM) was associated with an increase in response rate (RR: $32 \%$ vs. 14\%) [26].

The second phase III trial was the randomized AVAiL study assessing the efficacy and safety of bevacizumab dosed at 7.5 and $15 \mathrm{mg} / \mathrm{kg}$ in combination with cisplatin/ gemcitabine. The trial confirmed bevacizumab's benefits in terms of progression-free survival (similar efficacy and safety of both doses); it failed, however, to demonstrate improvements in terms of overall survival $[2,3,7,8]$.

One of the most common adverse reactions to bevacizumab is the development of arterial hypertension ( $1 / 3$ of patients; stages 3 and 4 of arterial hypertension were observed in $18 \%$ of patients treated with bevacizumab) [27]. Hypertension most likely develops as a result of the inhibition of nitric oxide production caused by the blockage of VEGF action leading to increased vascular tension. Other hypotheses underscore the reduced density of capillaries and the development of embolic microangiopathy in the renal vessels, leading to disturbances in the regulation of the renin-angiotensin system [2, 3, 28]. Nonetheless, researchers emphasize the positive predictive value of the occurrence of arterial hypertension during treatment with bevacizumab [29].

Other adverse reactions observed in clinical studies include gastro-intestinal perforations, fistulas, wound-healing impairment, proteinuria, and vascular complications such as arterial and venous thromboembolisms, bleeding (including hemoptysis), as well as congestive heart failure and myocardial infarction.

Although bevacizumab is the only registered agent in the treatment of non-small-cell lung cancer, it is not widely used in therapy.

\section{Small-molecule anti-angiogenic tyrosine kinase inhibitors}

Sorafenib is an oral multikinase inhibitor. Its action is aimed at inhibiting tumor growth (by inhibiting Raf, c-kit, Flt-3) and impeding the development of new vessels (by acting on VEGFR-2, VEGFR-3, and PDGFR- $\beta$ ). Its most commonly observed adverse effects are diarrhea (> 25\%), palmoplantar erythrodysesthesia (hand-foot syndrome), fatigue, and nausea [30]. After 2 months of treatment, study E2501 demonstrated that a significantly larger number of patients responded favorably to the treatment (SD/PR/CR) in comparison to the placebo group (47\% vs. 19\%); PFS was 3.6 vs. 2.0 months, OS was 11.9 vs. 9.0 months. The randomized phase III ESCAPE trial, encompassing 926 patients with advanced non-small-cell lung carcinoma, compared the efficacy of carboplatin/paclitaxel chemotherapy and chemotherapy combined with sorafenib in the first line of treatment. No statistically significant differences were confirmed in terms of RR, PFS, or OS between the two groups, which resulted in the early termination of the trial [31].

Sunitinib is a small-molecule multikinase inhibitor. Its action consists in the inhibition of tumor cell proliferation, new vessel formation, kinase activity of VEGFR-1, -2, and -3 , as well as of PDGFR- $\alpha$ and $-\beta$, tyrosine kinase similar to Fms-3 (Flt3), c-kit, and tyrosine kinase of the receptor encoded by the RET proto-oncogene [32, 33]. Its most common adverse effects are fatigue, pain, myalgia, nausea, vomiting, dyspnea, stomatitis, and gastritis. Another important adverse effect is skin discoloration, probably related to the yellow color of the active ingredient; hair may become discolored as well.

Pazopanib blocks the kinase activity of VEGFR-1, VEGFR-2, VEGFR-3, PDGFR, and c-kit (34). It has been demonstrated that, after pazopanib treatment, the serum levels of VEGFR-2 and PIGF are significantly reduced and, additionally, correlate with the degree of neoplastic tumor reduction [35].

Vandetanib is an oral angiogenesis inhibitor acting on VEGFR-2, VEGFR-3, and the EGFR/HER1 receptor as well as an inhibitor of tumor growth acting on RET. Numerous clinical studies have reported higher objective treatment response rates in groups treated with vandetanib in comparison to groups with chemotherapy alone. A phase III clinical study (ZODIAC) assessed the combination of vandetanib and docetaxel in the second-line treatment of patients suffering from advanced non-small-cell lung carcinoma. The addition of vandetanib prolonged progression-free survival (PFS 4.0 vs. 3.2 months); however, no prolongation of overall survival was observed [36]. The most frequent adverse effects of this therapy included rash, diarrhea, and asymptomatic prolongation of the QTC interval. Another phase III clinical study (ZEIST) demonstrated that, in patients with advanced non-small-cell lung carcinoma, after the failure of previous chemotherapy, vandetanib and erlotinib exhibit similar efficacy in terms of PFS and OS, but vandetanib treatment is associated with substantially increased toxicity [37].

\section{Nintedanib}

Nintedanib (BIBF 1120) is an oral triokinase inhibitor, assessed in clinical studies, which inhibits the activity of vascular endothelial growth factor receptor 1-3 (VEGFR 1-3), fibroblast growth factor receptor 1-3 (FGFR 1-3), and platelet-derived growth factor $\alpha$ and $\beta$ (PDGFR $\alpha$ and $\beta$ ). Nintedanib acts on three types of cells: endothelial cells (VEGFR 1-3, FGFR 1-3), smooth muscle cells (FGFR 1-3, PDGFR $\alpha$ and $\beta$ ), and pericytes (PDGFR $\alpha$ and $\beta$ ). It has been suggested that the signaling pathways associated with FGFR and PDGFR 
are responsible for the development of potential mechanisms of the loss of control over neoplastic cells via signaling pathways associated with VEGFR, which are blocked by anti-angiogenic agents and, thus, constitute an alternative mechanism of neoplasm progression. Therefore, blocking three tyrosine kinases responsible for the angiogenic process appears to be a promising starting point for new targeted therapies [38, 39].

Considering the period over which it acts on target cells and some of its pharmacokinetic parameters, BIBF 1120 differs from other angiogenesis inhibitors. After exposing cell cultures to BIBF 1120 in a concentration of $50 \mathrm{nmol} / \mathrm{l}$ for 1 hour, the inhibition of receptor phosphorylation was maintained for at least 32 hours, indicating long-lasting anti-angiogenic action [40].

A multicenter, randomized, double-blinded, and placebo-controlled phase III clinical study (LUME-Lung 1) assessed the efficacy and safety of using nintedanib after failure of the first line of treatment for locally advanced or metastatic non-small-cell lung carcinoma (IIIb/IV according to the TNM classification). The study excluded patients with centrally located tumors, tumor necrosis or cavitation, and neoplastic large vessel invasion, as well as patients whose medical history indicated hemorrhagic or thrombotic events within the past 6 months or hemoptysis within the past 3 months. The study encompassed 1314 patients from Europe, Asia, and South Africa. One of the study groups received docetaxel dosed at $75 \mathrm{mg} / \mathrm{m}^{2}$ on the $1^{\text {st }}$ day and nintedanib dosed at $200 \mathrm{mg}$ twice per day on days 2-21 $(n=655)$, while the other group received docetaxel in the same dose and placebo $(n=659)$. The primary endpoint of the examination was progression-free survival; its prolongation was demonstrated in the patients receiving nintedanib independently of the histological subtype of the neoplasm (PFS: 3.4 months [95\% Cl: 2.9-3.9] vs. 2.7 months [95\% Cl: 2.6-2.8], $p=0.0019)$. It is worth noting that the study provided the earliest proof for the efficacy of using an anti-angiogenic agent in the $2^{\text {nd }}$ line of treatment with regard to prolonging overall survival; however, this pertained only to adenocarcinoma patients (OS: 12.6 months [95\% Cl: 10.6-15.1] vs. 10.3 months [95\% Cl: 8.6-12.2], $p=0.0359$ ). The most common adverse effects of administering nintedanib as compared with placebo were nausea (24\% vs. $18 \%$ ), emesis ( $17 \%$ vs. $9 \%$ ), diarrhea (42\% vs. $22 \%$ ), and increased liver enzyme activity (29\% vs. $8 \%$ ). All side effects were transient and abated when symptomatic treatment was employed or the dose was reduced [63]. The primary adverse events requiring the lowering of the nintedanib dose were gastrointestinal ailments and increased liver enzyme concentration. No increase in the frequency of adverse events characteristic of anti-angiogenic therapies, such as arterial hypertension, bleeding, or gastrointestinal tract perforation, was noted in the subgroup receiving nintedanib. More precise analyses indicated that adenocarcinoma patients in whom the disease progresses within a period shorter than 9 months from the beginning of 1st line chemotherapy achieve greater benefits in terms of overall survival from the use of docetaxel in combination with nintedanib than from treatment with docetaxel alone (OS: 9.8 months [95\% Cl: 6.1-15.5] vs. 6.3 months [95\% Cl: 5.0-8.1], $p=0.0246)$. These data may suggest that fast disease progression is a positive predictive factor in the case of nintedanib administration [41]. It has also been demonstrated that patients with neoplasms of greater mass before the start of therapy achieve more substantial benefits from treatment with docetaxel in combination with nintedanib [42].

\section{Radiological evaluation of anti-angiogenic treatment response - diagnostic pitfalls}

In patients treated with angiogenesis inhibitors in combination with chemotherapy, standard radiological evaluation according to the RECIST 1.1 criteria based on computed tomography with contrast does not enable the precise assessment of treatment response. Morphological changes are observed within the tumors, including the formation of cavities (cavitation), bleeding, bleeding into the tumor, necrosis, or changes in the density of the tumor's pattern.

It is assumed that cavitation occurs in neoplastic tumors due to the development of central necrosis associated with the inhibition of angiogenesis; their frequency in patients undergoing anti-angiogenic treatment is estimated at $19-24 \%$ [43, 45]. Nishino et al. demonstrated in their study that in $79 \%$ of patients undergoing anti-angiogenic treatment, the cavities are subsequently filled in, which is defined as a reduction of any dimension of an air-filled cavity (from the smallest reduction visible to the complete disappearance of the cavity) resulting from the growth of the solid tumor component within the cavitary area. The filling in of cavities is considered to be a morphological change, which corresponds to disease progression, but is not reflected in the evaluation of treatment response based on the RECIST 1.1 criteria [44, 45]. Crabb et al. [46] retrospectively evaluated the response to anti-angiogenic treatment of 33 patients, using the RECIST criteria and an alternative method, in which the largest dimension of the cavity was subtracted from the largest dimension of the target change, which correlated much more significantly with the change in tumor volume. The use of the abovementioned method, alternative to RECIST 1.1, resulted in a different treatment response, different time to best response, and time to disease progression, but this only pertained to a decided minority of patients [44].

Yoo Na Kim et al. evaluated anti-angiogenic treatment response with the use of dual-energy computed tomography (DECT), employing the criteria developed by Choi et al. and comparing the results with an evaluation conducted according to the RECIST criteria. The researchers noted that the appearance of bleeding within the tumor as a morphological change constituting a form of treatment response may imitate an increase in tumor dimensions and lead to an erroneous diagnosis of progressive disease (PD) instead of stable disease (SD) or partial response (PR) [47-49]. The Choi criteria, which were initially introduced for the monitoring of the efficacy of treating gastrointestinal stromal 
Tab. I. Comparison of treatment response according to the Choi and RECIST 1.1 criteria $[49,50]$

\begin{tabular}{|c|c|c|}
\hline Response & Choi criteria & RECIST 1.1 criteria \\
\hline CR & $\begin{array}{l}\text { Regression of all identified neoplastic foci } \\
\text { No new foci }\end{array}$ & $\begin{array}{l}\text { Regression of all identified neoplastic foci } \\
\text { No new foci }\end{array}$ \\
\hline PR & $\begin{array}{c}\text { A reduction in the total dimension* of evaluated foci by } \geq 10 \% \text {, } \\
\text { or a reduction in tumor density }(\mathrm{HU}) \text { by } \geq 15 \% \text { in } \mathrm{CT} \\
\text { No new foci } \\
\text { No progression in non-measurable foci }\end{array}$ & $\begin{array}{l}\text { A reduction in the total dimension of evaluated foci by } \geq 30 \% \\
\text { No new foci } \\
\text { No progression in non-measurable foci }\end{array}$ \\
\hline SD & Does not meet the criteria for $\mathrm{CR}, \mathrm{PR}, \mathrm{PD}$ & Does not meet the criteria for $\mathrm{CR}, \mathrm{PR}, \mathrm{PD}$ \\
\hline PD & $\begin{array}{c}\text { An increase in the total dimension* of evaluated foci by } \geq 10 \% \text {; } \\
\text { PR criteria are not met after tumor density (HU) in CT } \\
\text { is considered } \\
\text { New foci }\end{array}$ & An increase in the total dimension of evaluated foci by $>20 \%$ \\
\hline
\end{tabular}

${ }^{*}$ The total of the longest dimensions of measurable foci according to RECIST

$\mathrm{CR}$ - complete response, $\mathrm{PR}$ - partial response, SD - stable disease, PD - progressive disease

tumors with imatinib, are based on the evaluation of tumor density, defined as the CT attenuation coefficient measured in Hounsfield units (HU) (Table I) [49, 50].

Hence, evaluating treatment efficacy based only on $\mathrm{CT}$ images and according to the RECIST 1.1 criteria, which define treatment response based only on the changes in tumor size, may be inaccurate.

\section{Conclusions}

Anti-angiogenic treatment based on tumor biology is one of the more recently developed therapeutic options. Bevacizumab is the first anti-angiogenic agent for which prolongation of overall survival has been demonstrated in non-small-cell lung carcinoma patients in the first line of treatment. During clinical studies, the observed adverse effects necessitated the exclusion of patients with tumor cavitation or necrosis, patients with neoplastic invasion of large vessels or centrally located tumors, patients with the histological diagnosis of squamous carcinoma, and patients whose medical history indicated hemorrhagic or thrombotic events. The only anti-angiogenic agent demonstrated to improve overall survival in non-small-cell lung carcinoma patients in the $2^{\text {nd }}$ line of treatment is nintedanib (LUME-Lung 1 study); this pertains, however, only to patients with the histopathological diagnosis of adenocarcinoma. The search for biomarkers constituting predictive factors for anti-angiogenic treatment response is ongoing. It has been demonstrated that the development of arterial hypertension during therapy is a factor associated with better response to treatment with bevacizumab, while, in the case of nintedanib treatment for pulmonary adenocarcinoma patients, a better response is achieved in patients who did not respond to the first line of treatment, or in whom the disease progressed shortly after the end of therapy. As a result of treatment, morphological changes occur within the tumor, including the formation of cavities/necrosis or bleeding into the tumor. Bleeding within the tumor may imitate an increase in tumor dimensions and lead to an erroneous diagnosis of PD. Similarly, the diagnosis may be incorrect if, within the cavity resulting from the anti-angiogenic treatment, the solid tumor component from the cavity grows, while the tumor itself does not change its dimensions.

\section{References}

1. Hicklin DJ, Ellis LM. Role of the vascular endothelial growth factor pathway in tumor growth and angiogenesis. J Clin Oncol 2005; 23: 1011-1027.

2. Gridelli C, Rossi A, Maione P. New antiangiogenetic agents and non-small cell lung cancer. Crit Rev Oncol Hematol 2006; 60: 76-86.

3. Ulahannan SV, Brahmer JR. Antiangiogenic agents in combination with chemotherapy in patients with advanced non-small cell lung cancer. Cancer Investigation 2011; 29: 325-337.

4. Blau HM, Banfi A. The well-tempered vessel. Nat Med 2001; 7: 532-534.

5. Folkman J. Angiogenesis: an organizing principle for drug discovery? Nat Rev Drug Discov 2007; 6: 273-286.

6. Jain RK. Normalizing tumor vasculature with antiangiogenic therapy: a new paradigm for combination therapy. Nat Med 2001; 7: 987-989.

7. Wojtukiewicz MZ, Sierko E. Leczenie ukierunkowane na cele molekularne w onkologii i hematoonkologii. Via Medica, Gdańsk 2013.

8. Herbst RS, Onn A, Sandler A. Angiogenesis and lung cancer: prognostic and therapeutic implications. J Clin Oncol 2005; 23: 3243-3256.

9. Meert AP, Paesmans M, Martin B, Delmotte P, Berghmans T, Verdebout JM, Lafitte JJ, Mascaux C, Sculier JP. The role of microvessel density on the survival of patients with lung cancer: a systematic review of the literature with meta-analysis. Br J Cancer 2002; 87: 694-701.

10. O’Bryne KJ, Konkourakis MI, Giatromanolaki A, Cox G, Turley H, Steward WP, Gatter K, Harris AL. Vasculat endothelial growth factor, platelet-derived endothelial cell growth factor and angiogenesis in non-small cell lung cancer. Br J Cancer 2000; 82: 1427-1432.

11. Ushijima C, Tsukanoto S, Yamazaki K, Yoshino I, Sugio K, Sugimachi K. High vascularity in the peripheral region of non-small cell lung cancer tissue is associated with tumor progression. Lung Cancer 2001; 34: 233-241.

12. Fontanini G, Lucchi M, Vignati S, Mussi A, Ciardiello F, De Laurentiis M, De Placido S, Basolo F, Angeletti CA, Bevilacqua G. Angiogenesis as a prognostic indicator of survival in non-small cell carcinoma: a prospective study. J Natl Cancer Inst 1997; 89: 881-886.

13. Auguste $P$, Lemiere $S$, Larrieu-Lahargue F, Bikfalvi A. Molecular mechanisms of tumor vascularization. Crit Rev Oncol Hematol 2005; 54: 53-61.

14. Carmeliet P. Mechanisms of angiogenesis and arteriogenesis. Nat Med 2000; 6: 389-395.

15. Connolly DT, Heuvelman DM, Nelson R, Olander JV, Eppley BL, Delfino JJ, Siegel NR, Leimgruber RM, Feder J. Tumor vascular permeability factor stimulates endothelial cel growth and angiogenesis. J Clin Invest 1989; 84: 1470-1478.

16. Senger DR, Galli SJ, Dvorak AM, Perruzzi CA, Harvey VS, Dvorak HF. Tumor cells secrete a vascular permeability factor that promotes accumulation of ascites fluid. Science 1983; 219: 983-985.

17. Ferra N, Gerber HP, LeCouter J. The biology of VEGF and its receptors. Nat Med 2003; 9: v669-676.

18. Brown LF, Yeo KT, Berse B, Yeo TK, Senger DR, Dvorak HF, van de Water L. Expression of vascular permeability factor (vascular endothelial growth fac- 
tor) by epidermal keratinocytes during wound healing. J Exp Med 1992; 176 : 1375-1379.

19. Dvorak HF. Vascular permeability factor/vascular endothelial growth factor: A critical cytokine in tumor angiogenesis and a potential target for diagnosis and therapy. J Clin Oncol 2002; 20: 4368-4380.

20. Yoshiji H, Kuriyama S, Hicklin DJ, Huber J, Yoshii J, Ikenaka Y, Noguchi R, Nakatani T, Tsujinoue H, Fukui $H$. The vascular endothelial growth factor receptor KDR/Flk-1 is a major regulator of malignant ascites formation in the mouse hepatocellular carcinoma model. Hepatology 2001; 33: 841-847.

21. Yuan F, Chen Y, Dellian M, Safabakhsh N, Ferrara N, Jain RK. Time-dependent vascular regression and permeability changes in established human tumor xenografts induced by an anti-vascular endothelial growth factor/vascular permeability factor antibody. Proc Natl Acad Sci 1996; 93:14765-14770.

22. Giaccone G. The potential of antiangiogenic therapy in non-small cell lung cancer. Clin Cancer Res 2007; 13: 1961-1970.

23. Cao R, Brahenhielm E, Li X, Pietras K, Widenfalk J, Ostman A, Eriksson U, Cao Y. Angiogenesis stimulated by PDGF-CC, a novel member in the PDGF family, involves activation of PDGFR-alphaalpha and -alphabeta receptors. FASEB J 2002; 16: 1575-1583.

24. Reinmuth N, Liu W, Jung YD, Ahmad SA, Shaheen RM, Fan F, Bucana CD, McMahon G, Gallick GE, Ellis LM. Induction of VEGF in perivascular cells defines a potential paracrine mechanism for endothelial cell survival. FASEB J 2001; 15: 1239-1241.

25. Dong J, Grunstein J, Tejada M, Peale F, Frantz G, Liang WC, Bai W, Yu L, Kowalski J, Liang X, Fuh G, Gerber HP, Ferrara N. VEGF-null cells require PDGF alpha signaling-mediated stromal fibroblast recruitment for tumorigenesis. EMBO J 2004; 23: 2800-2810.

26. Yamashita J, Ogawa M, Abe M, Nishida M. Platelet-derived endothelial cell growth factor/thymidine phosphorylase concentrations differ in small cell and non-small cell lung cancer. Chest 1999; 116: 206-211.

27. Dowlati A, Gray R, Sandler AB, Schiller JH, Johnson DH. Cell adhesion molecules, vascular endothelial growth factor and basic fibroblast growth factor in patients with non-small cell lung cancer treated with chemotherapy with or without bevacizumab - an Eastern Cooperative Oncology Group Study. Clin Cancer Res 2008; 14: 1407-1412.

28. Knetki-Wróblewska M, Płużański A, Krzakowski M. Nadciśnienie tętnicze a leczenie ukierunkowane molekularnie - powikłanie czy biomarker skutecznej terapii. Onkol Prakt Klin 2011; 6,7: 279-291.

29. Horn L, Sandler AB. Angiogenesis in the treatment of non-small cell lung cancer. Proc Am Thorac Soc 2009; 6: 206-217.

30. Dahlberg S, Sandler A, Brahmer J, Schiller JH, Johnson DH. Clinical course of advanced non-small cell lung cancer patients experiencing hypertension during treatment with bevacizumab in combination with carboplatin and paclitaksel on ECOG4599. J Clin Oncol 2010; 28: 949-954.

31. Gatzemeier U, Blumenschein G, Fosella F. Phase II trial of single-agent sorafenib in patients with advanced non-small cell lung carcinoma. ASCO meeting, Abstract 2006; 24: 7002.

32. Scagliotti G, Novello S, von Pawel J, Reck M, Pereira JR, Thomas M, Abrão Miziara JE, Balint B, De Marinis F, Keller A, Arén O, Csollak M, Albert I, Barrios $\mathrm{CH}$, Grossi F, Krzakowski M, Cupit L, Cihon F, Dimatteo S, Hanna N. Phase III study of carboplatin and paclitaksel alone or with sorafenib in advancer non-small cell lung cancer. J Clin Oncol 2010; 28: 1835-1842.

33. Socinski MA. The current status and evolving role of sunitynib in non-small cell lung cancer. J Thoracic Oncol 2008; 3 (6, Suppl. 2): 119-123.

34. Socinski MA, Novello S, Brahmer JR. Multicenter, phase III trial of sunitynib in previously treated advanced non-small cell lung cancer. J Clin Oncol 2008; 26: 650-656.

35. Kumar R, Knick VB, Rudolph SK, Johnson JH, Crosby RM, Crouthamel MC, Hopper TM, Miller CG, Harrington LE, Onori JA, Mullin RJ, Gilmer TM, Truesdale AT, Epperly AH, Boloor A, Stafford JA, Luttrell DK, Cheung M. Pharma- cokinetic-pharmacodynamic correlation from mouse to human with pazopanib, a multikinase angiogenesis inhibitor with potent antitumor and antiangiogenesis activity. Mol Cancer Ther 2007; 6: 2012-2021.

36. Nikolinakos PG, Altorki N, Yankeletvitz D. plasma cytokine and angiogenic factor profiling identifies markers associated with tumor shrinkage in early-stage non-small cell lung cancer patient treated with pazopanib. Cancer Res 2010; 70: 2171-2179.

37. Heymach JV, Johnson BE, Prager D. Randomized, placebo-controlled, phase II study of vandetanib plus docetaxel in previously treated non-small cell lung cancer. J Clin Oncol 2007; 25: 4270-4277.

38. Natale RB, Thongprasert S, Greco FA. Vandetanib versus erlotynib in patients with advanced non-small cell lung cancer after failure of at least one prior cytotoxic chemotherapy: a randomized, double-blind, phase III trial (ZEST). J Clin Oncol 2009; 27: 409, abstract 8009.

39. Hilberg F, Roth GJ, Krssak M, Kautschitsch S, Sommergruber W, TontschGrunt U, Garin-Chesa P, Bader G, Zoephel A, Quant J, Heckel A, Rettig WJ. BIBF 1120: triple kinase inhibitor with sustained receptor blockade and good antitumor efficacy. Cancer Res 2008; 68: 4774-4782.

40. Casanovas O, Hicklin DJ, Bergers G, Hanahan D. Drug resistance by evasion of antiangiogenic targeting of VEGF signaling in late-stage pancreatic islet tumors. Cancer Cell 2005; 8: 299-309.

41. Hilberg F, Roth GJ, Krssak M, Kautschitsch S, Sommergruber W, TontschGrunt U, Garin-Chesa P, Bader G, Zoephel A, Quant J, Heckel A, Rettig WJ. BIBF 1120: triple angiokinase inhibitor with sustained receptor blockade and good antitumor efficacy. Cancer Res 2008; 68: 4774-4782.

42. ASCO, 3-6 czerwca, Atlanta 2006, 24 (18, Suppl.): pp. 3015.

43. Reck $M$ et al. Nintedanib (BIBF1120) plus docetaxel in non-small cell lung cancer patients progressing after first line chemotherapy: LUME-Lung-1, a randomized, double-blind phase 3 trial. Oral presentation at the 49th Annual Meeting of the American Society of clinical Oncology (ASCO), Chicago, I, USA, 31 May-4 Jun 2013.

44. Meleungaard A, Kaiser R, Douillard JY, et al. Analysis of overall survival in adenocarcinoma non-small cell lung cancer patients receiving 2 nd line combination treatment with nintedanib (BIBF1120) plus docetaxel in the LUME-Lung 1 trial: a randomized, double-blind, placebo-controlled phase 3 study. Oral presentation on 29 Sep 2013 at the European Cancer congress 2013, Abstract no 3409.

45. Nishino M, Cryer SK, Okajima Y, Sholl LM, Hatabu H, Rabin MS, Jackman DM, Johnson BE. Tumoral cavitation in patients with non-small cell lung cancer treated with antiangiogenic therapy using bevacizumab. Cancer Imaging 2012; 12: 225-236.

46. Crabb SJ, Patsios D, Sauerbrei E, Ellis PM, Arnold A, Goss G, Leighl NB, Shepherd FA, Powers J, Seymour L, Laurie SA. Tumor cavitation: impact on objective response evaluation in trials of angiogenesis inhibitors in non-small cell lung cancer. J Clin Oncol 2009; 27: 404-410.

47. Wilson AG, Hansel DM. Immunologic diseases of the lung. Imaging of the Diseases of the Chest 2000; 533-636.

48. Kim YN, Lee HY, Lee KS, Seo JB, Chung MJ, Ahn MJ, Park K, Kim TS, Yi CA. Dual-energy $C T$ in patients treated with anti-angiogenic agents for nonsmall cell lung cancer: new method of monitoring tumor response? Korean J Radiol 2012; 13: 702-710.

49. Choi H, Charnsangavej C, Faria SC. Correlation of computed tomography and positron emission tomography in patients with metastatic gastrointestinal stromal tumor treated at a single institiution with imatinib mesylate:proposal of new computed tomography response criteria. J Clin Oncol 2007; 25: 1753-1759.

50. Senkus-Konefka E. Nowe kryteria odpowiedzi na leczenie w przypadku guzów litych. Zmodyfikowane zalecenia RECIST (wersja 1.1). Med Prakt Onkol 2009. 